\title{
$\left({ }_{2}\right.$ PSSR \\ Pakistan Social Sciences Review www.pssr.org.pk
}

\section{RESEARCH PAPER}

\section{Deep Ecology and the Rhetoric of Critical Dystopia in Piers Torday's The Last Wild}

\author{
Faryal Waheed ${ }^{1}$ Dr. Shahzeb Khan* 2
}

1. M. Phil Scholar, Institute of English Studies, University of the Punjab, Lahore, Punjab, Pakistan

2. Assistant Professor, Institute of English Studies, University of the Punjab, Lahore, Punjab, Pakistan

\begin{tabular}{|c|c|}
\hline PAP & \\
\hline $\begin{array}{l}2021 \\
: \\
2021\end{array}$ & $\begin{array}{l}\text { This paper employs the theoretical framework of Tom Moylan's } \\
\text { concept of Critical Dystopia and the biospheric egalitarian } \\
\text { principle of Arne Naess's Deep ecology philosophy to explore } \\
\text { the representation of various environmental injustices in Piers } \\
\text { Torday's The Last Wild. The issues explored include interspecies } \\
\text { and intergenerational environmental injustice and the }\end{array}$ \\
\hline $\begin{array}{l}\text { Inism, } \\
\text { ystopia, } \\
\text { logy, } \\
\text { opia, } \\
\text { ental }\end{array}$ & $\begin{array}{l}\text { disproportionate distribution of the environmental burdens and } \\
\text { benefits between the population of the developed and } \\
\text { developing countries. It also studies climate change as a cultural } \\
\text { phenomenon resulting from the anthropocentric culture. It } \\
\text { expose score components of climate change such as } \\
\text { industrialization, capitalism, and techno centricity that have not } \\
\text { only destroyed the natural world but also threatened the }\end{array}$ \\
\hline $\begin{array}{l}\text { ponding } \\
\text {.english }\end{array}$ & $\begin{array}{l}\text { survival of the human species. In addition to exposing the } \\
\text { destructive tendencies of the anthropocentric worldview, the } \\
\text { paper also attempts to highlight the ecotopian vision of deep } \\
\text { ecology as a solution for contemporary social and ecological } \\
\text { problems. }\end{array}$ \\
\hline
\end{tabular}

\section{Introduction}

A critical dystopian narrative provides an ideal setting for exploring the environmental injustice issues from deep ecology's point of view. The postapocalyptic narrative in The Last Wild not only comments on the vulnerability of the natural world in the face of a global climate catastrophe but also exposes the resulting fragility and injustices in human society. This paper is concerned with the portrayal of a dark and dangerous future (Bratton, 2015) in the children's climate fiction as a rhetorical device to endorse the moral, ethical and eco-centric stance of deep ecology as opposed to the dominant anthropocentric worldview. Divided into two parts; the first part will develop the relationship between dystopia and deep ecology by finding the foundational similarities between Tom Moylan's concept of 
critical dystopia and Arne Naess's holistic deep ecology philosophy. The second section explores how the dystopian rhetoric strategy decenters the dominant anthropocentric worldview to promote the 'deepist' values in the narrative. It also focuses on the utopian impulse inherent in both critical dystopia and deep ecology philosophy that put faith in human agency and activism to find solutions for environmental and social challenges to create a holistic and just society.

The theoretical framework of this paper is predominately informed by the critical theoretical writings of Greg Garrard on ecocriticism and apocalyptic science fiction literature and Tom Moylan's concept of Critical dystopia. Garrard (2012) says that the relationship between ecocriticism and dystopia is strong because it gives the idea that humans must think about survival than demise. After all, they show that the world is not going to end (Dror, 2014). Instead of frightening people to evoke activism hope can bear fruitful results, Naess has also argued that the need is to put forward a "utopian vision of future" (Gare, 2014, pp. 203-204). The genre-blurring tendencies of critical dystopia are reflected in the dystopian-utopian narrative. Based on Moylan's (2000) assertion that Dystopia has a "complex relationship to the utopian impulse" (p. 122) this paper explore show the nightmarish dystopian world of The Last Wild reveals the underlining deep ecological utopian vision through a dialectical negation of utopian impulse.

In environmental fiction, dystopian and apocalyptic imagination is indispensable in promoting ecocentric environmental values (Fuchs, 2018; Rigby, 2011) as it serves the dualistic purpose of exposing the faults of the dominant world view and call for reformation in the present society (Moylan, 2000). In eco-dystopias "Western worldview prevails" (Slaughter, 1998, p. 997) and the narrative focuses on the "ecocidal tendencies" (Bouson, 2016, p. 346) of this dominant worldview by depicting it as a threat to the survival of all life forms. It links the devastation of the human and non-human world with the idealism of the Enlightenment, industrial and scientific revolution (Çiftcibaşı, 2016)the engendered the exploitative core values of the Western civilizations such as consumerism, domestication, and dominion over nature, technocentricity (Bouson, 2016), "capitalism and imperialism" (Moylan, 2000, p. xiv). Therefore, in its focus on the destructive tendencies of the dominant worldview dystopia holds the pedagogical and political potential (Wegner, 2002) that shows humanity "the way not to inhabit the Earth" (Naess, 1989, p. 187). Deep ecology shares dystopia's weariness of exploitative tendencies of Western anthropocentric perspective and strives to save both human and non-human world from human exploitation and domination (Bodian, 1995).

As Garrard elucidates dystopia is a "genre born out of crisis" (Garrard, 2012, p. 94) that opens in a futuristic society that is "considerably worse than the society in which that reader lived" (Sargent, 1994, p. 9) with a major focus on issues such as overpopulation, corporate profiteering, and the absence of deep ecological thinking (Otto, 2006). The representation of the future presented in such texts serves as deep ecology's nightmare as they present social and ecological conditions that deep ecology aims at avoiding. These texts illustrate the negative adaptation of the surviving population in an environmentally ruined society (Setyorini, 2016). Thus, 
the frightful consequences of contemporary practices in an imaginary world serve as a rhetorical tool that urges humanity to adopt "more ecologically conscious ways of thinking and being" (Otto, 2006, p. 79) to avoid a similar fate.

Moreover, the environmental apocalyptic imagery of the eco-dystopian fiction is reflected in the stance of some anti-humanist proponents of the radical environmental group Earth First! - that combined the deep ecological beliefs with tragic apocalypticism (Garrard, 2012). Radical environmentalism has an ecoapocalyptic sensibility that believes in the "imminent ecological crisis and biological meltdown" (Bouson, 2016, p. 343) and abandons all hopes for the survival of humanity. Although both dystopia and radical environmentalism share a foundational similarity in their use of the myth of the end of human civilization (Cremier, 2014) yet the precise function of apocalypticism is that it offers some hope that the crisis can be averted (Garrard, 2012). Garrard (2012) believes that "only if we imagine that the planet has a future, after all, are we likely to take responsibility for it" (p. 116). This intertextual link of utopian and dystopian imagination is what Moylan (2000) has termed as "Critical Dystopia" (p. xv).

To elaborate, Moylan (2000) asserts that through a "dialectical negation" (p. 191) dystopia expresses its utopianism impulse that is an "expression of desire" (p. 191). This desire is reflected in critical dystopia's "refusal of the modern society" (p. xii) and rejection of stagnant ideals through an articulation of oppositional views and promotion of radical action (Moylan, 2000). Therefore, they reveal what deep ecologist Devall and Session (1985) has stated: "the distance between what ought to be and what is now a reality in our technocratic industrial society" (p. 162). Furthermore, Moylan (2000) claims those critical dystopias find their utopian idealism in their emancipatory, militant and open stance and redirect the multiplicity and diversity of voices into a collective voice against the hegemonic system of oppression. Critical dystopias are radical and reformist in nature therefore they do not merely aim at revealing the symptoms but focus on finding the cause (Moylan, 2000). Similarly, Arne Naess does not approve of the shallow approach of modern civilization to repair the symptoms rather than seriously eliminating the causes of destruction of ecosystem and biodiversity loss (Naess, 1989).

Another way the critical dystopia borders on the utopian spectrum is its introduction of the possibility of reformation by the "virtue of human effect" (Moylan, 2000, p. 156). The "comic frame of [the] apocalypse" does not illustrate evil "as guilt, but as error" (Dürbeck, 2012, p. 26) and provides humanity a chance to redeem itself through the recognition of its failure to be "good stewards of nature and the environment" (p. 27). After the realization of its fallibility, humanity tries to bring change through its actions and breaks the cycle of oppression to form a more holistic society where interspecies harmony, equality, and spiritual connection with nature persist as a fulfillment of deep ecological vision (Otto, 2006). 
However, in ecodystopian texts, deep ecological thinking is "dismissed and criminalized" (Otto, 2006, p. 95). Similarly, in the text under study crisis stems from the violation of deep ecology's principle of biospheric egalitarianism that is responsible for the degradation of both the human and non-human world. Moreover, the eco-dystopia opens in an ecologically devastated world, similarly, the text open in a broken ecological world where anthropogenic global warming and resulting desertification of land and rising sea level has made the rest of the world inhabitable except a single "cold grey rock - the Island"(Torday, 2013, p. 5). Not only have human activities rendered the earth inhabitable for humans but oceanic pollution has made the living conditions impossible for marine life. The great whale laments this loss by telling Kester that "Man filled the wet with his sail-shells, trailing knotted traps and pumping out slick. As he spread over the earth, so the creatures the first great-fish had sung vanished until there were nearly none left" (Torday, 2015, p.59). Sharing a similar fate the majority of animals and birds except the varmints have succumbed to the red-eye virus while the remaining non-human population was exterminated to prevent the spread of infection to humans (Torday, 2013)

Consequently, these ecological devastations have directly altered the living conditions of the surviving population (Setyorini, 2016) who in addition to the scarcity of living space is faced with the scarcity of food resources. Kester narrates:

First, the animals we eat went, and then the bees went, and then the crops and fruit went. Vegetables were contaminated. So there were rations, the remaining supplies of fresh food stockpiled in giant deep freezes. Then all that went too. We lived out of tins. Oily, meaty, fishy or veggie mush out of tins. The tins began to run out too. People started eating anything. Even varmints. Rats. Cockroaches.(Torday, 2013, p. 11)

Therefore, in the absence of natural food resources, the human population has to rely on a universal meal replacement called "Formula-A" (Torday, 2015, p. 267) - a pink mush that has different flavors that satisfy their "daily nutritional needs" (Torday, 2013, pp. 11, 12). And despite their efforts to manage the "dwindling resource" (Torday, 2015, p. 121), they are "running out of the raw ingredients for formula" (Torday, 2014,p. 247)too as the human population has exceeded the planet's carrying capacity. The scientist could not find any possibility to accommodate or feed the rapidly expanding population, so they cannot ensure the "quality of life" (Torday, 2015, p. 123) they once enjoyed. The human population explosion in the text mirrors the overpopulation issue of our contemporary world where the world population that was around 5 billion in 1987 has reached 7.8 billion in 2020 and is expected to reach 10.8 billion in 2100 (Roser et al., 2013). Margret Atwood's fears that a similar fate awaits contemporary humanity and has warned them by stating that "the rules of biology are as inexorable as those of physics; run out of food and water and you die. No animal can exhaust its resource base and hope to survive. Human civilization is subjected to the same law" (as cited in Bouson, 2016, p. 342). These fictional and real-world concerns draw our attention to the fourth tenant of deep ecology that states that "The flourishing of human life and 
cultures is compatible with a substantial decrease ofthe human population. The flourishing of nonhuman life requires such a decrease"(Naess, 1995a, p. 68).

Conversely, deep ecologists believe that exponential human growth is responsible for several problems such as problems like "intensifying resource extraction, accelerating environmental and habitat destruction, mass extinction of plant and animal species, and ever-worsening ecological degradations" (Bouson, 2016, p. 342). Human overcrowding jeopardizes the chances of survival for nonhuman species with the destruction of their habitats and scarcity of natural resources. It violates the biospheric egalitarian principle that not only endorses the "equal right to live and blossom" (Naess, 1973, p. 96) for all species but focuses on the protection of their habitats too (Naess, 1989). Correspondingly the dark wild resents humanity for subjecting them to the same conditions. Dagger says, that "One human after another, breeding and filling every available inch of the earth for their towers and their roads, taking every last drop of water, every last gulp of air for themselves. They will not stop breeding till they have covered what remains of the earth" (Torday, 2014, p. 317).

However, the text reflects that the real issue is not simply the human overpopulation but the higher destructive impact of few elites in that population whose development and prosperity are achieved at the expense of nature. This leads us to the popular population reduction debate in contemporary environmentalism that stresses the disparity in the ecological impact of the affluent and economically underprivileged countries (Garrard, 2012). The per capita destruction rate of the developed countries is hundred times higher than the developing nations that is why deep ecologists criticize shallow ecology for its call for the reduction of population in the developing countries while ignoring the disproportionate environmental impact of the developed countries (Bodian, 1995).

Therefore the text points out that overpopulation is not the sole culprit for the violation of the eco-spheric egalitarian principle but the greed and selfishness of the few humans. The exploitive capacity of capitalistic culture is embodied in the character of Selwyn Stone. For instance, in his opinion, the virus not only rid the world of "unpredictable and unreliable" (Torday, 2015, p.259) wild animals and plants but created an opportunity for him to invent a universal food replacement so humans would no longer have to depend on "animal-based products" (p. 263)in the face of scarcity of natural resources. Although from a human-centered point of view, his intentions may seem 'noble', done in the best interest of humanity yet his brother Eck, reveals that under the pretense of humanity's welfare he was trying to fulfill his selfish agendas (p. 37). He wanted the human population to solely rely on his Formula therefore when Eck found a miracle plant "Omnium" on the "Faraway Island" (p. 267)that could satisfy all nutritional requirements; he tried to destroy the plant and the island containing it(Torday, 2015).His desire to make a profit knew no bounds therefore in the end "it wasn't just nature and food he wanted to dominate ... but everything" (p. 259). Being the head of the powerful enterprise that "run[s] 
everything"(Torday, 2013, p. 9) on the island from "from hospitals to schools" (p. 14)he dictates all the rules to control the people on the island. Stone's will to dominate everything makes it clear that the "problem of domination" (De Jonge, 2011, p. 309) inherent in the anthropocentric perspective is not limited to the exploitation of the natural world but it applies equally to fellow humans. The most compelling evidence of his greed is that to ensure people's dependence on his formula he not only used his bioengineered plague to exterminate the animals but to destroy the agriculture in the country as well. "Facto destroyed the vegetables and crops, saying they were contaminated"(Torday, 2013, p. 140), all through the countryside lay the rotting remains of crops that once grew in those fields(Torday, 2013). The farmers lost their "best beast", "prize herd"(p. 213) and crops to the plague, and not only did he take away a major mean of sustenance for many families living in the countryside of the Island, but he also declared the countryside a "quarantine zone" (p. 234) and coerced the people to live in his glass towers that will keep them save from the virus (Torday, 2013). The people who did not believe the virus was real and stayed behind were labeled "outsiders" and denied the Formula that was "only meant for good law-abiding city folk, not wicked outsider types" (pp. 51, 156). His horrific plans for humanity and earth make him a representative of the exploitative Western capitalistic system that thrives at the expense of the human and natural world.

Conversely, the microcosmic dystopian world provides a "creative take on the problems of current social order" (Moylan, 2000, p. 145) with its "disproportionate environmental impact" (Garrard, 2012, p. 107) on the human population. Global climate change hits everyone differently due to the discrepancy in mitigation and adaptation to change resulting from different socio-environmental systems (Mirzoeff, 2018). Thereupon, deep ecologist asserts that the underprivileged faction of the society will be more vulnerable in the case of a climatic event (Bodian, 1995). Comparably, outside the Glass Towers, Kester saw a huge crowd of hungryfaced Outsiders in their threadbare clothes, chanting "'Food! Shelter" (Torday, 2015, p. 120).These people have lost what little they had in the great flood while the people living in the glass tower remained safe and sound (Torday, 2015).

In addition to the inequitable distribution of natural resources, the text also focuses on the disproportionate "system of environmental burdens" (Kopnina, 2014, p. 1) by highlighting the issue of "garbage imperialism" (Stebbins, 1993, p. 82). Garbage imperialism, "toxic colonialism" or "Third World dumping" (p. 81) refers to a growing trend of exportation of developed nation's hazardous waste to developing countries (Stebbins, 1993). Taking advantage of the lenient or nonexistent environmental laws of the Third world countries, the First World nations, "geographically and mentally distance" (Varkkey, 2019)themselves from this toxic fruit of their development to ensure ceaseless overconsumption and consumerism. These rich countries hide behind their "environmentalist credentials" (Stebbins, 1993, p. 81) and tempt the poor nations with the "waste-related revenue" (p. 97)to shoulder the burden of their environmental responsibilities. Although waste picking provides employment and income opportunity to the population living near these 
landfills (Edmond, 2019) yet the contaminated air and water supply resulting from poor waste management facilities put them at peril (Stebbins, 1993; Thelwell, 2019). It is estimated that each year around 400,000 and 1 million people in developing countries die due to poor health conditions resulting from "mismanaged waste" (Edmond, 2019).

Identically, to keep the most important and biggest megacity Premium clean and pollution-free, the discarded waste is dumped into the Waste Town (Torday, 2015). A shabby town housing a great number of underprivileged climate refugees living in midst of heaps of rubbish (Torday, 2014). The whole place is filled with tents, caravans, half-naked children, mountains of rubbish, and a horrible stench. The huge "mountain of rubbish" (p. 61) containing dead fridges, broken furniture, and wires resembles South Asia's "largest uncovered landfill" in Bantar, with its trash mounds rising to ten stories high(Thelwell, 2019). And the multilevel rubbish tower in Littleman's cave with salvaged computers, music players, headphones, and watches (Torday, 2014) bears a striking resemblance to the world's largest e-dump site in Agbogbloshie, Ghana that house the discarded electronic goods from around the globe (Edmond, 2019). The waste mountain is the symbol of "human criminal recklessness toward each other and toward the environment" (Yosef-Paz, 2018, p. 69 ) and exposes the disproportionate environmental burden between developed and underdeveloped nations.

Furthermore, not only does the Waste Town resemble the third world dumping sites in physical appearance but matches the poor living conditions of its residents accurately. Everywhere the rubbish pickers could be seen pulling their "piled high" (Torday, 2014, p. 60) junk cart or collecting rubbish in a "green bin strapped to their backs" (p. 60)to find something valuable they could sell. The people have "hungry, hollow eyes" (p. 62) because much like the outsiders these waste pickers do not have access to Formula. Commenting on this disparity Aida tells Kester that the real formula is "running out. There's enough for everybody. Unless you live in one of them glass towers" (p. 73). Therefore, they have to rely on a cheap version of the formula "Pink" that was made "from recycled rubbish" (p. 72). The foul-smelling "acrid liquid" (p. 73) can prove deadly if it is consumed after its "four-hour time limit" (p. 73). As reflected in the text, the deplorable condition of nature and humanity resulting from the Western capitalistic culture violates the biospheric egalitarian principle of deep ecology that envision a harmonious society where all the species, human and non-human, have equal rights to live and enjoy the natural resources (Bodian, 1995). And by the extension of the same rule deep ecology criticizes the shallow ecological approach for its efforts to maintain and improve the living standards of humanity while compromising the "ruling socioeconomic order" (Garrard, 2012, p. 21-22).

Keeping in with the convention of critical dystopia that gives space and voice to the "dispossessed and denied subjects" (Moylan, 2000, p. 198), the text has not only highlighted the plights of non-human and socio-economically marginalized 
groups but it has also identified another vulnerable group - the future generation. Similarly, the fourth aspect of environmental justice focuses on intergenerational injustice and stresses that the current generation's exploitative practices and excessive consumption of natural resources will endanger the survival of the future generation (Kopnina, 2014). Deep ecology also shares a similar concern for the future generation, Naess himself said that deep ecology "feel responsible for future generations, not just the first, but the second, third, and fourth generation as well" (Bodian, 1995, p. 29). Gary Synder has harshly critiqued humanity as "a locust-like blight on the planet that will leave a bare cupboard for its own children" (as cited in Devall \& Sessions, 1985, p. 171). You (2020) stipulates that in the rapidly altering environment the child like the non-human animal is an equally "vulnerable and subaltern figure, who must also shoulder the burden of a species' plight framed by adult faults" (p. 4). Kester expresses similar sentiments when his father tries to stop him and his friends to go on a dangerous mission to find a way to save the world. He says, that "We are the only ones prepared to find another way to save the earth? Yet again, it's left to us to sort out your mess" (Torday, 2015, p.161). Equally important are the issues of the future generation in the poor countries who are bearing both the social and intergenerational environmental burden. Aida and her Waste mountain gang symbolize this third world "anthropogenic strays"(You, 2020, p. 13), who like the animals have "dispossessed lives" (p. 13). Littleman boasts that along with the "inanimate junk" (Torday, 2014, p. 78)these orphan and homeless kids are also a part of his collection. He provided them boarding and lodging when their parents could not feed them anymore (Torday, 2014). Here the kids in the "Waste Mountain Gang" (p. 71) work together and steal food to keep them all fed (Torday, 2014).

However, these representatives of the "betrayed generation" (You, 2020, p. 12) are not passive and voiceless as they stand up against the injustice and oppression of the "hegemonic structure" (Moylan, 2000, p. xiii). The protagonist and his young allies are the "agents of change and citizens being denied their full human rights" (Op de Beeck, 2018, p. 84). While the "animals-loving" (Torday, 2013, p.155)children, Kester and Polly, are the defenders of the non-human world, Aida, on the other hand, is the champion of the underprivileged humanity with her anticapitalistic stance (Torday, 2015). Together these children enter into an "outright opposition" (Moylan, 2000, p. xiii) to the unjust and oppressive system of their society and remedy it by the means of their 'deep' concern for the human and nonhuman world. This role of young adult agency in dystopian fiction not only reflects the hope for the future but restores the faith in the goodness of humanity whose actions can save the world from destruction (Fuchs, 2018). As Sargent (1994) says that "dystopias are self-consciously warnings. A warning implies that choice, and therefore hope" (p. 26) thus in eco-dystopia the choices and actions of the protagonist and his allies not only determine the fate of the non-human and human world (Leatherland, 2018) but provides hope for humanity redemption (Dürbeck, 2012). 
Furthermore, the hope for salvation resides in the militant stance protagonist and his allies and their refusal to accept the "status quo" (Moylan, 2000, p. xiii). In the "militant political action" (p. 173), eco-dystopia envisions the possibility of a "warrior society" (Bouson, 2016, p. 347) that refuses to "compromise on the defense of life" (p. 347). Correspondingly, several disjointed militant efforts rose against Facto one such example is Polly's parents, Mr. and Mrs. Goodacre who along with the country folks like Ma were developing a secret weapon against Facto (Torday, 2014). The secret weapon, Iris, was a collection of billions of microdots that contained a "record of everything the virus and the cullers took away"(p. 239), the genetic code of all the extinct flora fauna species could help them restart the world (Torday, 2014). Kester's father, Professor Jaynes developed a cure for the red-eye virus, and Aida's mother, a teacher, and a journalist went after Facto to expose the lies about their "scientific research" (p. 223). Yet Facto crushed all these efforts and revolts by the means of imprisonment, blackmail, and murder (Torday, 2014).

Despite these threats, the defenders of life do not even care for their own lives in the line of their mission. Even Naess has urged his eco-warriors to "try to act resolutely and without cowardice in conflicts, but to remain non-violent in words and deeds" (Naess, 1995b, p. 261). Similarly, in his confrontation with Dagger on the Amsguard, Kester does not try to harm the dog rather he tries to restore the dark wild's trust in humanity with his attempt to save Dagger's life at the cost of his own life (Torday, 2014). Not only does his sacrifice win him their trust, but they also accept him as their leader, "Wildness" (Torday, 2013, p. 190) something no human has been able to achieve before (Torday, 2013). Another self-sacrificing figure in the text is Eck, who unlike his egocentric brother Stone, is a true eco-warrior who lay down his life while defending humanity's sole hope the Omnium plant. Eck's death in his defense nature illustrates the real examples of various eco-activists who paid for activism with their life such as Cambodia's, anti-logging activist Chut Wutty, a Costa Rican conservationist Jairo Mora Sandoval and Kenule 'Ken' Beeson SaroWiwa(Kopnina, 2015).

However, the critical dystopian text retains its utopian impulse in the victory of the dissident group against the dominant structure therefore the "collective resistance" (Moylan, 2000, p. xiii) led by Kester and his friends not only shattered the trust of people in Facto (Torday, 2014) but it also mends their severed connection with the natural world. For instance, when Kester walked back into the city with the group of last surviving animals - The Last Wild - the people hid in their homes out of the fear of the virus (Torday, 2013) but after the people realized that Stone has spread these lies about the virus to make them solely reliant on Facto for their sustenance they were not "frightened of touching animals anymore" (Torday, 2015, p. 133). In the same manner, when the wronged animals got united under the dark wild to wage a war on humanity to seek revenge for the countless years of cruelty and oppression, Kester averted the crisis by showing them that people like him and his friends have helped the animals with their cure for the virus and they "can help make this earth a better place" (Torday, 2014, p. 309) for everyone. Reflecting the 
deep ecology's egalitarian principlehe appeals to the dark wild that even though "We have made mistakes, but we have the right to live here too" (p. 321). His actions not only renewed the relationship between the human and non-human world but also unified the last wild and dark wild that made the previously marginalized animals "stronger than before" (p. 340). Therefore as a true vanguard of deep ecology, he defeated the anthropocentric system and establishment a "wholesome ecological community" (You, 2020, p. 12). Although he has mended the broken relationship between humanity and nature, a greater threat is still looming on their heads. The great fires from the sky threaten the survival of all life forms he needs to find a solution to save the planet from destruction(Torday, 2015).

As the predicted "end of the world" (Torday, 2015, p. 415) approaches Stone has made the preparations for space colonization to an Earth-like planet "Nova" (p, 131) in his Advanced Relocation Craft (ARC) that can support any life form. Stone says, that each pod in his ARC "can deliver nutrients, air, and water to every kind of creature from a man to a ... Stag" (pp. 127-128). This "external escape to new habitat, or new worlds" (Slaughter, 1998, p. 997)is a common trope in the dystopian narrative that provides hope for humanity's survival by providing an "escape route" (p. 997). Yet this escape plan provides the text an opportunity to further foreground the contrast in Kester's optimistic and deepest stance and the resigned and shallow stance of the other characters. While Stone and the others plan on creating a new settlement on another planet he makes the case "of making this one right"(Torday, 2015, p. 302). He says, that "Everyone's proper excited about the prospect of a whole new earth. A planet with clean air and water, with room for us all to start over. Everyone apart from me, that is. What's to stop us repeating the mistakes we made on this one?"(p. 133).

He points that the exploitative and selfish ways that humans have dealt with the earth that is responsible for the destruction of the planet and if they do not change the anthropocentric ways they will continue the earth-bound ravages on the new planet. He stresses that humans need to change the things around them, not the planet (Torday, 2015). He does not see the situation as "a closed matter" but sees the possibility of creating a "utopian enclave" (Moylan, 2000, p. 153)by bringing a change through positive human action. He thinks, "This city, this Island, this world - it's our home. If it's dying, we have to find the cure. If a fire is coming, we have to stop it" (Torday, 2015, p. 74). His optimism resonates with the utopian dystopia's tendency to transform the "bad place" by the "virtue of human efforts" (Moylan, 2000, p. 156).

Another reason why Kester is apprehensive of this plan is that he knows that it won't be for all of them as there will be animals and humans Stone will not want on his ARC (Torday, 2015, p. 154). And his worst fear is realized when "the poor, the very young, he weak and the old of Premium, denied entry to the ARC" (p. 335). Despite his best efforts to stop the space mission, Kester fails. While the majority of the human population along with Kester's father and Polly left for Nova he stayed behind with his animal friends and remaining humans to survive the final apocalyptic event (Torday, 2015). Commenting on the uncertainty of their situation, 
Kester says, that "We are, all of us, humans and animals alike, entering the unknown ... in the dark below. Where we hold each other, as the world beyond burns" (p. 386). The great fires burnt all the marks of human civilization and in their place, a new "city of blue and green" (p. 393)emerged with ample food, "land, water, rain, sun and air" (p. 397). This utopian enclave illustrates the aspiration of deep ecology that stresses equal distribution and access to natural resources for all species (Bodian, 1995). The utopian impulse of the text offers the possibility of a "new paradise" built "over the debris" (Torday, 2015, p. 394)of the old world in the memory of "all those who believed in the power of nature" (p. 394). In the classical utopian dystopian convention, the text promises the possibility of a fresh start to humanity who has learned from its mistakes. In this regard, not only the surviving population on earth will be a better version of itself but the people gone off to the distant planet will create another utopia under the leadership of Polly and Professor Jaynes(Torday, 2015).

Furthermore, the space colonization project also provided a harmless solution for the issue of over-population unlike the catastrophic solution predicated by Crutzen(2016) who believes that unless a "global catastrophe" such as "a meteorite impact, a world war or a pandemic" (p. 212) reduce the human population, humanity will remain a "major environmental force for many millennia" (p. 212). In the same manner, the misanthropic stance of a few radical ecologists resonates with Crutzen's prospect; they suggested that only through the means of disease, plague and flood can the earth get rid of the parasitic humanity (Bouson, 2016; Garrard, 2012). Although the humans in the text were headed towards a similar fate yet the optimistic and utopian tendencies of the text saved them from total annihilation and resolved the issue of overpopulation by introducing the possibility of another place to live. And thus as a manifestation of Gary Snyder's proposition, reducing the population to a half or less than half of the current number (Devall \& Sessions, 1985).

\section{Conclusion}

To conclude, a critical dystopian narrative is an effective rhetorical tool in disseminating deep ecological values. Through "dialectical negation" (Moylan, 2000, p. 191), the suppression of deep ecological thinking in the nightmarish world of the novel foregrounds the underlying positive utopian impulse. Furthermore, the militant stance of the critical dystopia redeems humanity of its faults with its rejection and struggle against the dominant anthropocentric worldview and therefore, provides the solutions for the problems of human and non-human world in the biospherical egalitarianism principal of deep ecology. Lastly, by putting trust in positive human action, eco-dystopian texts have the potential to make us good humans by making us aware of the negative effect of our choice and lifestyle others and in turn, make us reconfigure our life choices and worldview. 


\section{References}

Bodian, S. (1995). Simple in Means, Rich in Ends: A Conversation with Arne Naess. In Deep Ecology for the Twenty-First Century (pp. 26-36): Shambhala.

Bouson, J. B. (2016). A "joke-filled romp" through end times: Radical environmentalism, deep ecology, and human extinction in Margaret Atwood's eco-apocalyptic MaddAddam trilogy. The Journal of Commonwealth Literature, 51(3), 341-357.

Bratton, D. (2015). Recent Fiction by Joan Givner, Lydia Millet, and Amy Plum: Cli-fi Takes Off into a Dark Future. Jeunesse: Young People, Texts, Cultures, 7(2), 183-193.

Çiftcibaşı, A. (2016). The Earth Burning Away and Society Falling Apart: The Drought as Ecological Dystopia 2. Inquis Journal, 27-42.

Cremier, L. (2014). Evaluate the Role of Utopian Thinking in Green Political Thought. www.e-ir.info/2014/11/10/evaluate-the-role-of-utopian-thinking-in-greenpolitical-thought/.

Crutzen, P. J. (2016). Paul J. Crutzen: a pioneer on atmospheric chemistry and climate change in the Anthropocene. In Hans Günter Brauch (Ed.), (Vol. 50, pp. 211-215): Springer.

De Jonge, E. (2011). An alternative to anthropocentrism: Deep ecology and the metaphysical turn. In Anthropocentrism (pp. 307-320): Brill.

Devall, B., \& Sessions, G. (1985). Deep ecology: living as if nature mattered. Salt Lake City, UT: Peregrine Smith.

Dror, S. (2014). The ecology of dystopia: an ecocritical analysis of young adult dystopian texts. University of British Columbia,

Dürbeck, G. (2012). Popular Science and Apocalyptic Narrative in Frank Schätzing's The Swarm. Ecozon@: European Journal of Literature, CultureEnvironmental ethics, $3(1)$.

Edmond, C. ( 2019). This Is What the World's Waste Does to People in Poorer Countries. www.weforum.org/agenda/2019/05/this-is-what-the-world-s-waste-does-topeople-in-poorer-countries.

Fuchs, M. (2018). “What if Nature Were Trying to Get Back at Us?": Animals as Agents of Nature's Revenge in Horror Cinema. In American Revenge Narratives (pp. 177-206): Springer.

Gare, A. (2014). Deep ecology, the radical enlightenment, and ecological civilization. The Trumpeter, 30(2), 184-205. 
Garrard, G. (2012). Ecocriticism: Routledge.

Kopnina, H. (2014). Environmental justice and biospheric egalitarianism: Reflecting on a normative-philosophical view of human-nature relationship. Earth Perspectives, 1(1), 1-11.

Kopnina, H. (2015). Revisiting the Lorax complex: Deep ecology and biophilia in cross-cultural perspective. Environmental Sociology, 1(4), 315-324.

Leatherland, D. P. (2018). Deconstructing Anthropomorphism: The" Humanimal" Narratives of Kenneth Grahame, Beatrix Potter, and Richard Adams. (Doctor of Philosophy), Durham University,

Mirzoeff, N. (2018). It's not the Anthropocene, it's the white supremacy scene; or, the geological color line. After Extinction, 123-150.

Moylan, T. (2000). Scraps of the Untainted Sky: Science Fiction, Utopia, Dystopia: Westview Press.

Naess, A. (1973). The shallow and the deep, long-range ecology movement. A summary. Inquiry, 16(1-4), 95-100.

Naess, A. (1989). From ecology to ecosophy, from science to wisdom. World Futures: Journal of General Evolution, 27(2-4), 185-190.

Naess, A. (1995a). The Deep Ecological Movement. In Deep Ecology for the TwentyFirst Century (pp. 64-84): Shambhala.

Naess, A. (1995b). Deep Ecology and Lifestyle. In (pp. 259-262): Shambhala.

Op de Beeck, N. (2018). Children's Ecoliterature and the New Nature Study. Children's Literature in Education, 49(1), 73-85.

Otto, E. (2006). Science fiction and the ecological conscience: University of Florida.

Rigby, K. (2011). Imagining catastrophe: utopia and dystopia in a warming world. Arena Journal(35/36), 57.

Roser, M., Ritchie, H., \& Ortiz-Ospina, E. (2013). World population growth. Our World in Data.

Sargent, L. T. (1994). The three faces of utopianism revisited. Utopian studies, 5(1), 137.

Setyorini, A. (2016). Ecology, Technology and Dystopia: an Ecocritical Reading of Young Adult Dystopian Literature. Paper presented at the International Conference on Language, Literary, and Cultural Studies (ICON LATERALS). 
Slaughter, R. A. (1998). Futures beyond dystopia. Futures, 30(10), 993-1002.

Stebbins, K. R. (1993). Garbage imperialism: health implications of dumping hazardous wastes in Third World countries. Medical anthropology, 15(1), 81-102.

Thelwell, K. (2019, 26 July). Living in Landfills: Poverty In the Developing World. borgenproject.org/living-in-landfills-poverty-in-the-developing-world

Torday, P. (2013). The Last Wild: Quercus Books.

Torday, P. (2014). The Dark Wild: Quercus Books.

Torday, P. (2015). The Wild Beyond: Quercus Books.

Varkkey, H. (2019, July 29, 2019). By exporting trash, rich countries put their waste out of sight and out of mind. https://edition.cnn.com/2019 /07 /29/opinions/by-exporting-trash-rich-countries-put-their-waste-out-of-sightand-out-of-mind-varkkey/index.html

Wegner, P. E. (2002). Imaginary communities: utopia, the nation, and the spatial histories of modernity: University of California Press.

Yosef-Paz, N. B. (2018). Hebrew Dystopias: From National Catastrophes to Ecological Disasters. Israel Studies Review, 33(2), 66-84.

You, C. (2020). The Necessity of an Anthropomorphic Approach to Children's Literature. Children's Literature In Education, 1-17. doi:https:/ / doi.org/10.1007/s10583-020-09409-6 